\title{
Pre-Weaning Growth Traits in Nigerian Indigenous Pig Crossbreds
}

\author{
0. O. Oluwole*, A. K. Tiamiyu, T. O. Olorungbounmi, M. O. Oladele-Bukola, N. A. Akintoye \\ Institute of Agricultural Research and Training, Obafemi Awolowo University, Ile-Ife, Nigeria \\ Email:"oluwafunmike@yahoo.co.uk
}

Received 14 June 2014; revised 23 July 2014; accepted 18 August 2014

Copyright (C) 2014 by authors and Scientific Research Publishing Inc.

This work is licensed under the Creative Commons Attribution International License (CC BY). http://creativecommons.org/licenses/by/4.0/

(c) (i) Open Access

\section{Abstract}

Forty-seven hybrid progenies from crossbreeding between the Nigerian indigenous pig (NIP) and Large white pigs were used. Body measurements and live weight were recorded weekly from first week of birth to their weaning date. Body measurements taken were Body Weight (BW), Body Length (BL), Body Height (BH), Heart girth (HG) and Rump circumference (RC) of crossbred progenies. The correlation between the reproductive parameters and growth performance of hybrid pigs were established with good management practice. The mean for weaning weight was $6.72 \pm$ 0.02 , birth weight $0.91 \pm 0.13$, litter size at birth $5.36 \pm 1.87$, litter size at weaning $5.29 \pm 1.97$, litter weight at birth $4.56 \pm 1.57$, total litter weight at weaning $33.91 \pm 11.6$, average daily weaning weight $0.73 \pm 0.12$, average litter size at birth $0.93 \pm 0.11$ and sex ratio $97.78 \% \pm 8.61 \%$. The male and female mean values for weight of animals were $6.96 \pm 1.0$ and $6.52 \pm 0.9$ with male heavier in weight and higher in morphometric traits such as body length, heart girth and rump circumference, while the female were high in morphometric traits such as snout length, ear length and body height. The correlation matrix for body weight against linear body measurements in preweaned NIP crossbreds indicates that all the parameters could be used to select for body weight. The linear equation generated by regressing body weight on snout length, body height, rump circumference, heart girth and body length could be used by resource poor pig farmers in the estimation of body weight of pre weaned crossbreds pigs if they cannot afford weighing scales.

\section{Keywords}

Morphometric Measurement, Hybrid, Crossbreeding, Correlation, Nigerian Indigenous Pigs

\section{Introduction}

Crossbreeding is a successful management practice for improving litter productivity in swine [1]. It is also an

"Corresponding author.

How to cite this paper: Oluwole, O.O., Tiamiyu, A.K., Olorungbounmi, T.O., Oladele-Bukola, M.O. and Akintoye, N.A. (2014) Pre-Weaning Growth Traits in Nigerian Indigenous Pig Crossbreds. Agricultural Sciences, 5, 891-896.

http://dx.doi.org/10.4236/as.2014.510096 
effective means of improving reproductive performance, i.e., heterosis or hybrid vigour that comes from an increase in heterozygosity, which leads to better average genotypic values at dominant loci. This offers the opportunity to increase genetic variation from which leaner and more efficient animals can be selected [2]. Evaluation of the performance of animals constitutes an essential part of successful breeding plans for sustainable genetics improvement. In order to develop a very good model for the genetic improvement of crossed pigs, it is important to measure the traits of interest. Pigs are mostly kept for their meat and the most important trait of interest for their genetic improvement is the body weight. Body weight is an economically important trait [3]. Live weight might be affected by different management, environment and enterprise feeding conditions. Proper measurement of this trait on-farm is sometimes difficult because of unavailability of weighing scale in the rural areas. Therefore use of simple linear body measurement parameters to predict live weight will be appreciated by the farmers. Some traits are usually regulated by the same pair of genes. Hence information on associations between traits is highly valuable in genetic improvements. This study focused on age, reproductive parameters and the relationship between live weight and morphopogical parameters such as snout length (SL), body length (BL), hearth girth (HG), body height (BH) and rump circumferences (RC). It is also to determine the strength of relationship between bodyweight and linear body measurements, also to predict body weight from linear measurements.

\section{Materials and Methods}

The study was carried out at the Piggery unit of the Institute (I.A.R.T.). Forty-seven hybrid progenies were from crossbreeding between the NIP and Large white pigs. Body measurements were recorded weekly from first week of birth to their weaning date. Body measurements taken were Body Weight (BW), Body Length (BL), Body Height (BH), Heart girth (HG) and Rump (RC) of the progeny of crossed breed. Body Weight (BW), was measured with weighing scale, (BL), the length of the animal from the last cervical to the lumbar vertebra (base of the tail), Heart Girth (HG), the circumference of the chest region and rump circumference (RC) the circumference of the loin region; were measured with a measuring tape in centimeter. The data were analyzed using procedure correlation. The following parameters were taken Litter size at birth (total number of piglets farrowed), Litter birth weight (Weight of all the piglets farrowed), Average birth weight (total weight of the number born alive divided by the total weight of the live litter size at birth), Litter size at weaning (number of piglets at weaning), Litter weaning weight (total weight of the piglets in each litter) Average weekly gain pre-weaning (AWWG) (a weakly difference of piglet weight). The data were analyzed using the general linear model (GLM) procedures where the differences between the characteristics of the growth Data were summarized by using obtained variances for the estimation of morphometric traits and phenotypic correlations among pre-weaning traits such as BW, WW, LSB, LSW, ADWG, TBW, TWW, SR\%.

\section{Results and Discussion}

There was no significant ( $p>0.05$ ) effect of sex on the birth weight as shown below in Figure 1. This result was corroborated with findings of Adeooye et al. 2010 [4] where the pre-weaning weight of piglets from ASF survivors parents were not affected by sex. The heavier weight of male than females with $6.94 \mathrm{~kg}$ was in corroboration with Adeooye et al. [4], where the male was heavier than female with $7.13 \mathrm{~kg}$.

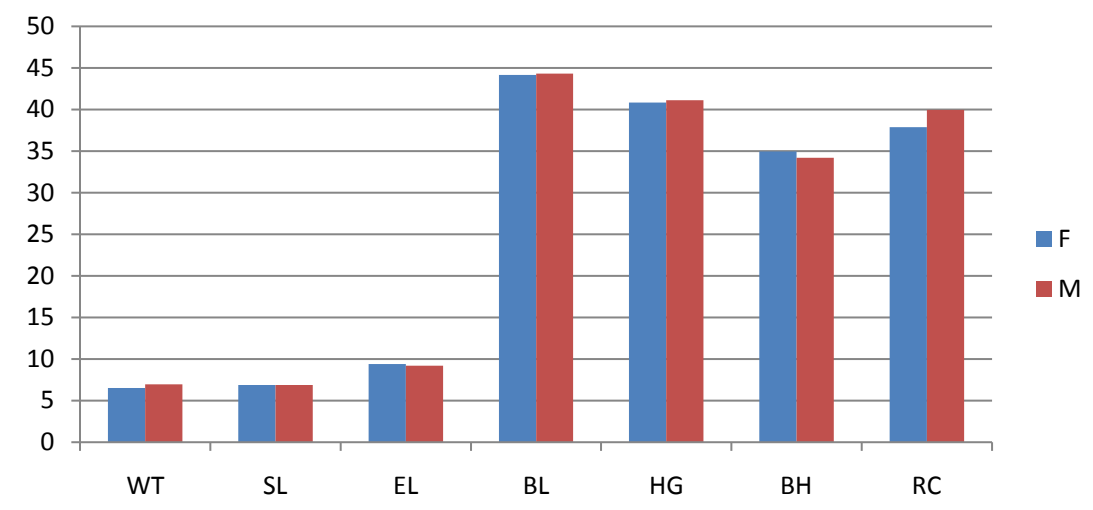

Figure 1. The non significant effect of sex on the body parameters. 
Tables 1-3 shows the mean for reproductive traits, the morphometric traits of hybrid pigs from age 1 to 7 week and the morphometric traits of male and female. In Table 1, the mean for weaning weight was $6.72 \pm 0.96$, birthweight $0.91 \pm 0.15$, litter size at birth $5.36 \pm 1.87$, litter size at weaning $5.29 \pm 1.97$, litter weight at birth $4.56 \pm 1.57$, total litter weight at weaning $33.91 \pm 11.6$, average daily weaning weight $0.73 \pm 0.12$, average litter size at birth $0.93 \pm 0.11$ and survival rate $97.78 \% \pm 8.61 \%$.

The results in Table 2 was similar with Adeooye et al. 2010 [4] in birth weight (1.05), weaning weight (7.08), litter size at weaning (5.72), but lower in litter weaning weight (38.85 kg) while it was higher than that of Orheruata [5] in weaning weight (4.87) and lower than that of Ngere [6] which is 14.50 . The litter size at birth is lower than that of Adebambo [7] and Nwakpu and Ugwu [8].

In Table 3, the male and female mean values for weight of animals were $6.96 \pm 1.0$ and $6.52 \pm 0.9$ with male heavier in weight and higher in morphometric traits such as body length, heart girth and rump circumference, while the female were high in morphometric traits such as snout length, ear length and body height with $6.88 \pm$ $0.6,9.39 \pm 1.2$ and $34.95 \pm 3.3$.

All the body parameters measured were positively and highly significantly $(\mathrm{p}<0.001)$ correlated with body weight (Table 4). The correlation coefficient ranges between 0.74 and 0.85 . The RC and BH had the highest correlation coefficient of 0.85 followed by HG and BH with values of 0.81 respectively.

Procedure of regression analysis was used to obtain best prediction equations for body weight from body measurement variables and the presented regression equations (Table 5) were obtained. For a unit increase in SL, BH, RC and HG, the body weight of pre weaned hybrid pigs will increase by $0.66,0.20,0.01$ and $0.11 \mathrm{~kg}$ respectively.

There was low correlation between the weaning weight and other reproductive traits with the exception of average weekly weight gain AWWG as shown in Table 6.

Table 1. Mean for reproductive traits of post weaned pigs.

\begin{tabular}{cl}
\hline Traits & Means + STD \\
\hline BW & $0.91 \pm 0.02 \mathrm{~kg}$ \\
BW & $0.91 \pm 0.03 \mathrm{~kg}$ \\
BW & $0.91 \pm 0.04 \mathrm{~kg}$ \\
BW & $0.91 \pm 0.05 \mathrm{~kg}$ \\
BW & $0.91 \pm 0.06 \mathrm{~kg}$ \\
BW & $0.91 \pm 0.07 \mathrm{~kg}$ \\
BW & $0.91 \pm 0.08 \mathrm{~kg}$ \\
BW & $0.91 \pm 0.09 \mathrm{~kg}$ \\
BW & $0.91 \pm 0.10 \mathrm{~kg}$ \\
\hline
\end{tabular}

BW—Birth weight, WW—Weaning weight, LSB — Litter size at birth, ALSB—Average Litter size at birth, LSW—Litter size at weaning, SR—survival rate.

Table 2. Mean and standard deviation for morphometric traits from week 1 - 7 weeks of pre-weaned pigs.

\begin{tabular}{ccccccc}
\hline \multicolumn{5}{c}{ Traits } \\
\hline WK & BW $\mathbf{( k g )}$ & SL $(\mathbf{c m})$ & BL $\mathbf{( c m )}$ & BH $(\mathbf{c m})$ & RC $(\mathbf{c m})$ & HG $(\mathbf{c m})$ \\
\hline 1 & 1.44 & $3.69 \pm 0.3$ & $23.03 \pm 4.7$ & $20.33 \pm 0.9$ & $22.90 \pm 5.8$ & $25.28 \pm 3.0$ \\
2 & 2.79 & $3.98 \pm 0.3$ & $27.08 \pm 1.2$ & $24.17 \pm 0.8$ & $28.00 \pm 2.7$ & $30.33 \pm 2.13$ \\
3 & 3.28 & $4.50 \pm 1.4$ & $30.64 \pm 4.3$ & $26.09 \pm 1.8$ & $32.91 \pm 2.6$ & $34.27 \pm 2.6$ \\
4 & 4.41 & $5.27 \pm 0.5$ & $34.00 \pm 1.2$ & $29.00 \pm 1.8$ & $34.54 \pm 2.7$ & $36.96 \pm 2.6$ \\
5 & 5.18 & $4.77 \pm 0.0$ & $36.37 \pm 4.8$ & $29.05 \pm 1.8$ & $39.18 \pm 2.6$ & $39.05 \pm 2.6$ \\
6 & 6.09 & $5.82 \pm 0.0$ & $40.55 \pm 4.8$ & $32.09 \pm 1.8$ & $44.27 \pm 1.9$ & $41.73 \pm 2.4$ \\
7 & 6.71 & $5.77 \pm 0.5$ & $42.73 \pm 4.5$ & $34.09 \pm 2.4$ & $46.46 \pm 2.6$ & $43.36 \pm 2.6$ \\
\hline
\end{tabular}

BW—Body weight, BL—Body Length, HG—Heart girth, NC—Neck circumference, SL—Snout Length, SC, TL—Tail length, RC-Rump circumference, BL—Body length, BH—Body height ( Height at wither). 
Table 3. The mean and SEM for the morphometric traits of male and female pre-weaning pigs.

\begin{tabular}{ccc}
\hline Traits & Males & Females \\
WT & $6.96 \pm 0.22 \mathrm{~kg}$ & $6.52 \pm 0.14 \mathrm{~kg}$ \\
SL & $6.86 \pm 0.10 \mathrm{~cm}$ & $6.88 \pm 0.17 \mathrm{~cm}$ \\
EL & $9.21 \pm 1.2 \mathrm{~cm}$ & $9.39 \pm 1.2 \mathrm{~cm}$ \\
BL & $44.33 \pm 0.16 \mathrm{~cm}$ & $44.18 \pm 0.71 \mathrm{~cm}$ \\
HG & $41.10 \pm 3.7 \mathrm{~cm}$ & $40.84 \pm 0.7 \mathrm{~cm}$ \\
BH & $34.19 \pm 0.69 \mathrm{~cm}$ & $34.95 \pm 0.70 \mathrm{~cm}$ \\
RC & $39.95 \pm 1.36 \mathrm{~cm}$ & $37.89 \pm 0.756 \mathrm{~cm}$ \\
\hline
\end{tabular}

Table 4. Pearson correlation Matrix of body weight and linear body measurements in pre-weaned NIP crossbreds.

\begin{tabular}{ccccccc} 
Variables & WT & SL & BL & BH & RC & HG \\
\hline WT & 1 & 0.81 & 0.74 & 0.85 & 0.85 & 0.81 \\
SL & & 1 & 0.68 & 0.71 & 0.73 & 0.76 \\
BL & & 1 & 0.76 & 0.84 & 0.79 \\
BH & & & 1 & 0.78 & 0.68 \\
RC & & & & 1 & 0.86 \\
HG & & & & & 1 \\
\hline
\end{tabular}

$\mathrm{WT}=$ weight, $\mathrm{BL}=$ Body length, $\mathrm{SL}=$ Snout length, $\mathrm{RC}=$ Rump circumference, $\mathrm{BH}=$ Body height, $\mathrm{HG}=$ Heart girth.

Table 5. Linear regressions relating body weight to various body linear measurements in pre-weaning NIP crossbreds.

\begin{tabular}{l}
$\begin{array}{l}\text { Regression Variable Coefficient of Determination }\left(\mathbf{R}^{2}\right) \\
\text { BLM }\end{array} \quad B W=-7.80-0.01 B L+0.66 S L+0.20 B H+0.01 R C+0.113 H G$ \\
\hline $\mathrm{R}^{2}=0.86 ; \mathrm{M}=$ Body linear measurement, $\mathrm{BW}=$ Body weight, $\mathrm{BL}=$ Body length, $\mathrm{SL}=$ Snout Circumference, $\mathrm{RC}=$ Rump circum- \\
ference, $\mathrm{HG}=$ Heart girth.
\end{tabular}

Table 6. Pearson correlation Matrix for reproductive traits.

\begin{tabular}{|c|c|c|c|c|c|c|c|}
\hline \multicolumn{8}{|c|}{ Traits } \\
\hline & WWT & BW & ADWG & ALSB & TLWTB & TLWW & S.R \% \\
\hline WWT & 1.00 & & & & & & \\
\hline BW & 0.23 & 1.00 & & & & & \\
\hline AWWG & 0.99 & 0.08 & 1.00 & & & & \\
\hline ALSB & 0.21 & 0.99 & 0.06 & 1.00 & & & \\
\hline TLWTB & -0.32 & 0.06 & -0.33 & 0 & 1.00 & & \\
\hline TLWW & -0.01 & -0.26 & 0.03 & -0.34 & 0.87 & 1.00 & \\
\hline S.R\% & 0.37 & 0.48 & 0.41 & -0.08 & 0.41 & -0.08 & 1.00 \\
\hline
\end{tabular}

The high correlation observed between litter size at birth and at weaning is expected because an increase in the number of piglet in a litter will cause an increment in the total litter weight. The correlation between the litter size and weaning weight is corroborated with the findings of Nwakwu, 2013 [9] and Nwakwu et al., 2004 [10], that there is positive and significant correlation between the liter size, weaning weight and survival rate of piglets. The negative correlation observed between litter size and average litter weight suggested that the factors 
that work for the increment of the litter size also cause reduction of average weight of the piglets. A highly negative and significant correlation between litter size and mean kit weight at birth of rabbit was reported by Nwakwu et al. (2004) [10]. The relationship between average piglet weight and liter size is however not invariable. Litter size has low heritability [10] and crossbreeding has been found to improve it [11].

The superior weaning weights of the crossbred pigs in this study also mean that the total litter weight at weaning was higher for the crossbred pigs and this was in line with Oluwole et al. [12]. Such findings could support the argument that crossbred pigs can be utilized under smallholder farming systems. Whittemore (1993) [13] suggested that the high weaning weights of crossbred pigs could also have been a reflection of their higher birth weights. Ncube, et al. (2003) [13] reported that the heavier piglets of the crossbred were better and able to compete for milk because they were thriftier and hence had higher chances of surviving up to weaning.

One of the most common and most useful statistics that describes the degree of relationship between two variables is the correlation [3]. The estimation of accurate body weight from animal's simple body measurements will make it easier for farmers in the rural area, who has little or no access to weighing scale. Due to affordability of measuring tapes a producer can measure all the body measurements easily from a live animal and can determine body weight approximately. Teghe and Olorunda (1998) [14] and Adeola (2009) [15] reported similar results between body weight and body measurements in pigs and, while Afolayan et al. (2006) [16], Salako (2006) [17] and Cankaya et al. (2009) [18] for sheep. In this study, there was high correlation between the weight and all the body linear measurement parameters taken. The highest correlations were found between body weights and rump circumference (RC) and body height (BH), while the lowest correlations were found between the body lengths (BL) and snout length (SL).

According to the correlation modules, body weight was found very highly correlated with all body dimensional traits measured $(0.74-0.85)$. Of the body dimensional characters, rump circumference and body height were the most related trait to weight and the correlation between these two traits was 0.85 . Variables such as heart girth, body height, body length, which are directly related to the size and weight of animal, showed moderate to very high positive correlations with each other $(0.68$ - 0.86). However, the measure of snout length was lowly correlated with body length (0.68). The high correlation coefficient observed between body weight and the linear body measurement parameters shows that selection for these traits will result in correlated responses in these traits.

In most studies heart girth was found to be highly correlated with body weight in pig [14], in sheep [16] [19] [20], in cattle [21]-[23] and in goat [24] [25]. The difference between this result and the mentioned literatures can be attributed to the differences in age, nutrition and or their rearing conditions.

Fattening status should be taken into consideration in order to predict an animal's bodyweight from its body measurements [26]. In this study results suggest that variables with high correlation coefficients might be used to predict body weight of pre weaned NIP crossbreds. Khan et al., 2006 [25] suggested that the highest relationships amongst body measurement may be used as selection criteria in traditional production systems in rural areas.

\section{Conclusion}

The correlation between the reproductive parameters and growth performance of hybrid pigs was established with good management practice. The correlation matrix for body weight against linear body measurements in pre-weaned NIP crossbreds indicates that all the parameters could be used to select for body weight. The linear equation generated by regressing body weight on snout length, body height, rump circumference, heart girth and body length could be used by resource-poor pig farmers in the stimation of body weight of pre-weaned crossbreds pigs if they cannot afford weighing scales.

\section{References}

[1] Oseni, S. (2005) Evaluation of the F1 and Backcrosses of Nigerian Local Pigs and the Large White for Litter Characteristics in Southwest Nigeria. http://pigtrop.cirad.fr

[2] Wheeler, M.B. and Campion, D.R. (1993) Animal Production-A Longstanding Biotechnological Success. American Journal of Clinical Nutrition, 58, 276S-281S.

[3] Cam, M.A., Olfaz, M. and Soydan, E. (2010) Possibilities of Using Morphometrics Characteristics as a Tool for Body Weight Prediction in Turkish Hair Goats (Kilkeci). Asian Journal of Animal and Veterinary Advances, 5, 52-59. http://dx.doi.org/10.3923/ajava.2010.52.59 
[4] Adeoye, A.O., Rotimi, E.A. and Njoku, C.P. (2012) Effect of Genotype and Sex on the Body Weight of Progenies of Pigs Produced by ASF-Recovered Pigs. 36th Annual Conference of Genetic Society of Nigeria, Calabar, 15-18 October 2012, 64-65.

[5] Orheruata, A.M. (2001) Evaluation of Response to Truncation Selection of Little Size Large White Pigs. Proceedings of 26th Annual Conference of NSAP, Zaria, 32-35.

[6] Ngere, L.O., Adu, I.F. and Mam, L. (1979) Report of Small Ruminant Breeding Subcommittee. NAPRI Bulletin 1, Ahmadu Bello University, Shika-Zaria.

[7] Adebambo, O.A. (1981) A Comparison of Indigenous and Exotic Purebred and Crossbred Sows in Southern Nigeria: Relationship between Dam and Litter Performance. Nigerian Journal Animal Production, 8, 67-74.

[8] Nwakpu, P.E and Ugwu, S.O.C. (2009) Heterosis for Litter Traits in Native by Exotic in Bred Pig Crosses. Agroscience, 8, 31-37. http://dx.doi.org/10.4314/as.v8i1.44111

[9] Nwakpu, P.E. (2013) Preweaning Litter Growth and Weaning Characteristics among Inbred and Cross Bred Native by Exotic Piglet Genotypes. Agriculture and Biology Journal of North America, 4, 393-397. http://dx.doi.org/10.5251/abjna.2013.4.4.393.397

[10] Nwakpu, P.E and Omeje, S.I. (2004) Heterosis for Body Weight in Native by Exotic in Bred Pig Crosses. Journal of Science, Agricultural Food Technology and Environment, 4, 50-60.

[11] Adebambo, O.A. (1986) Pig Improvement and Development in the Tropics: The Applications of Breeding and Genetics. Proceedings of the International Seminar on Pig Production in the Tropics, Nsukka.

[12] Oluwole, O.O., Tiamiyu, A.K., Olorungbounmi, T.O. and Adesehinwa, A.O.K. (2012) Estimation of Milk Yield and Correlation with Linear Body Measurement of Piglets from Nigerian Indigenous Pigs, Exotic and Crossbreds Sows. Global Advanced Research Journal of Agricultural Science, 1, 123-126.

[13] Ncube, M., Dzama, K., Chimonyo, M., Kanengoni, A. and Hamudikuwanda, H. (2003) Effect of Boar Genotype on Reproductive Performance of the Local Sows of Zimbabwe. Livestock Research for Rural Development, 15.

[14] Tegbe, J.S. and Olorunda, S.A.S. (1998) The Prediction of Live Weight of Crossbred Breed from Three Body Measurements. Nigerian Journal of Animal Production, 15, 9-13.

[15] Adeola, A.C. (2009) Morphological and Genetic Characterization of Nigerian Indegenous Pigs in Southern-Western Nigeria. Unpublished M.Sc. Thesis, Obafemi Awolowo University, Ile-Ife.

[16] Afolayan, R.A., Adeyinka, I.A. and Lakpini, C.A.M. (2006) The Estimation of Live Weight from Body Measurements in Yankasa Sheep. Czech Journal of Animal Science, 51, 343-348.

[17] Salako, A.E. (2006) Application of Morphological Indices in the Assessment of Type and Function in Sheep. International Journal of Morphology, 24, 13-18.

[18] Cankaya, S., Altop, A., Olfaz, M. and Erener, G. (2009) Canonical Correlation Analysis for Estimation of Relationships between Some Traits Measured at Pre- and Post-Slaughtering Periods in Karayaka Hoggets. Anadolu Journal of Agricultural Sciences, 24, 61-66.

[19] Topal, M. and Macit, M. (2004) Prediction of Body Weight from Body Measurements in Morkaraman Sheep. Journal of Applied Animal Research, 25, 97-100. http://dx.doi.org/10.1080/09712119.2004.9706484

[20] Atta, M. and El Khidir, O.A. (2004) Use of Heart Girth, Wither Height and Scapuloischial Length for Prediction of Live Weight of Nilotic Sheep. Small Ruminant Research, 55, 233-237. http://dx.doi.org/10.1016/j.smallrumres.2004.01.005

[21] Heinrichs, A.J., Erb, H.N., Rogers, G.W., Cooper, J.B. and Jones, C.M. (2007) Variability in Holstein Heifer HeartGirth Measurements and Comparison of Prediction Equations for Live Weight. Preventive Veterinary Medicine, 78, 333-338. http://dx.doi.org/10.1016/j.prevetmed.2006.11.002

[22] Koenen, E.P.C. and Groen, A.F. (1997) Genetic Evaluation of Body Weight of Lactating Holstein Heifers Using Body Measurements and Conformation Traits. Journal of Dairy Science, 81, 1709-1713. http://dx.doi.org/10.3168/jds.S0022-0302(98)75738-8

[23] Goe, M.R., Alldredge, J.R. and Light, D. (2001) Use of Heart Girth to Predict Body Weight of Working Oxen in the Ethopian Highlands. Livestock Production Science, 69, 187-195. http://dx.doi.org/10.1016/S0301-6226(00)00257-8

[24] Nsoso, B.S.J., Aganga, A.A., Moganetsi, B.P. and Tshwenyane, S.O. (2003) Birth Weight, Body Condition Score and Heart Girth in Indigenous Tswana Goats during Dry and Wet Season in Southeast Botswenyane. Livestock Research for Rural Development, 15.

[25] Khan, H., Muhammad, F., Ahmad, R., Nawaz, G., Rahimullah and Zubair, M. (2006) Relationship of Body Weight with Linear Body Measurements in Goats. Journal of Agricultural and Biological Science, 1, 51-54.

[26] Adeyinka, L.A and Mohammed, I.D. (2006) Relationship of Live Weight and Linear Body Measurement in Two Breeds of Goats of Northern Nigeria. Journal of Animal and Veterinary Advances, 5, 891-893. 
Scientific Research Publishing (SCIRP) is one of the largest Open Access journal publishers. It is currently publishing more than 200 open access, online, peer-reviewed journals covering a wide range of academic disciplines. SCIRP serves the worldwide academic communities and contributes to the progress and application of science with its publication.

Other selected journals from SCIRP are listed as below. Submit your manuscript to us via either submit@scirp.org or Online Submission Portal.
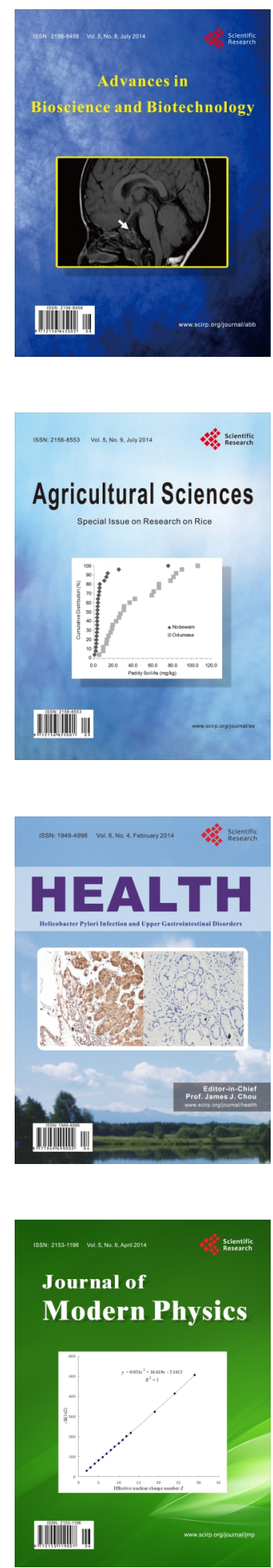
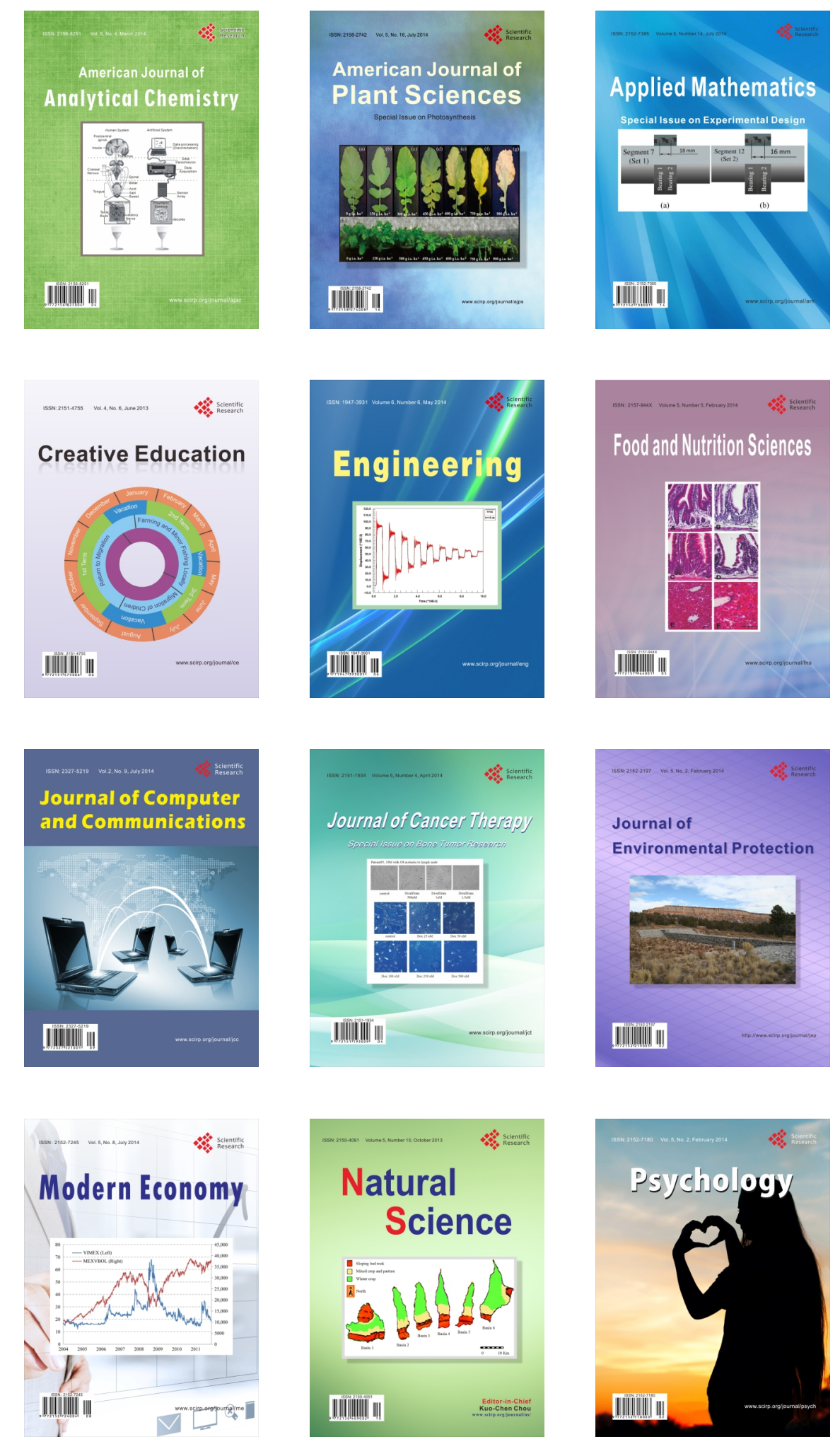